\title{
Resolusi Konflik Pencegahan Disintegrasi Bangsa Melalui Legalitas Hukum Syariat di Aceh ${ }^{\star}$
}

\author{
(National Disintegration Prevention Conflict Resolution \\ Through the Legality of Sharia Law in Aceh) \\ Muhammad Sholeh, ${ }^{1}$ Nur Rohim Yunus, ${ }^{2}$ Ida Susilowati ${ }^{3}$ \\ Institute PTIQ Jakarta, Universitas Islam Negeri Syarif Hidayatullah Jakarta, \\ Universitas Darussalam Gontor Ponorogo \\ E-mail: m.sholeh.ptiq@gmail.com, nurrohimyunus@uinjkt.ac.id, \\ idasusilowati@unida.gontor.ac.id

\section{dof $10.15408 /$ sjsbs.v3i3.7862}

\begin{abstract}
:
Efforts that have been made by the government of the Republic of Indonesia to reduce conflict in Aceh in the form of various policies. From the pattern of violence, mediation, enactment of the Regional Military Operation, to finally negotiations for peace. Negotiations eventually served as the final conflict resolution in order to quell the raging turmoil. After the Aceh Tsunami in December 2004, an agreement was finally reached in Helsinki between the government of the Republic of Indonesia and the elders of the Free Aceh Movement. Among the resolutions obtained are the enactment of Sharia law or Qonun in Aceh, as a legal law that regulates the life of the Acehnese in an Islamic manner.
\end{abstract}

Keywords: Conflict Resolution, Sharia Law, National Disintegration

\begin{abstract}
Abstrak:
Upaya yang telah dilakukan pemerintah Republik Indonesia dalam meredam konflik di Aceh dalam bentuk kebijakan beranekaragam. Dari pola kekerasaan, mediasi, pemberlakuan Daerah Operasi Militer, hingga perundingan untuk perdamaian. Perundingan akhirnya dijadikan sebagai resolusi konflik terakhir guna meredam gejolak yang berkecamuk. Pasca terjadinya Tsunami Aceh pada bulan Desember 2004, akhirnya dibuatkan kesepakatan di Helsinki antar pemerintah Republik Indonesia dan para tetua Gerakan Aceh Merdeka. Diantara resolusi yang didapatkan adalah pemberlakukan hukum Syariah atau Qonun di Aceh, sebagai hukum legal yang mengatur kehidupan masyarakat Aceh secara Islami.
\end{abstract}

Kata Kunci: Resolusi Konflik, Hukum Syariah, Disintegrasi Bangsa

* Diterima tanggal naskah diterima: 11 Maret 2016, direvisi: 22 April 2016, disetujui untuk terbit: 15 Mei 2016. 


\section{Pendahuluan}

Indonesia menetapkan bentuk Negara Kesatuan (unitary state) sebagai upaya mempersatukan kebhinekaan masyarakat. Dinamika perbedaan suku, ras, agama, etnis, budaya dan keragaman lainnya menjadikan Indonesia kaya akan budaya. Namun, kebhinekaan tersebut juga dapat menjadi kelemahan bangsa apabila pemerintah tidak mampu menjadi pemersatu bangsa, sehingga berubah menjadi konflik disintegrasi bangsa yang membahayakan masa depan bangsa. Permasalahan Aceh merupakan salah satu contoh konflik disintegrasi bangsa di Indonesia akibat ketidakadilan di bidang ekonomi yang berdampak pada konflik SARA, ditunjang dengan sistem desentralisasi di Indonesia. ${ }^{1}$ Hal tersebut sebagaimana disebutkan Sofyan Tan dalam salah satu tulisannya mengenai solusi ancaman disintegrasi bangsa bahwa ketidakadilan merupakan faktor utama tuntutan disintegrasi Aceh.

Pembicaraan tentang Aceh bukanlah hal yang baru, namun merupakan hal yang sudah lama sejak zaman sebelum kemerdekaan RI hingga pasca kemerdekaan. Berbagai cara telah ditempuh Pemerintah RI untuk menyelesaikan permasalahan ini, mulai dari dialog, penetapan Aceh menjadi daerah khusus, sampai akhirnya menjadi Daerah Operasi Militer (DOM), namun, hasilnya nihil. Pada tahun 2005 silam, telah terjadi nota kesepahaman perdamaian (MoU) antara Pemerintah RI dan GAM (Gerakan Aceh Merdeka) di Helsinki Finlandia. Perjanjian Helsinki yang ditandatangani tanggal 15 Agustus 2005 tersebut, menjadi perdebatan sengit di kalangan anggota legislatif, sebagian pengamat politik, akademisi dan sebagian masyarakat. Perdebatan ini banyak mempertanyakan isi nota kesepahaman yang notabene banyak merugikan pemerintahan RI dan mengancam keutuhan NKRI. Peristiwa tersebut menimbulkan pertanyaan mendasar, tentang cara apa yang dapat digunakan pemerintah untuk menyelesaikan konflik nasional di Aceh? Bagaimana tantangan dan solusi mengenai penerapan syariat Islam di Aceh? Kedua pertanyaan tersebut menjadi fokus bahasan pada artikel ini.

\section{Metode Penelitian}

Berangkat dari beberapa pertanyaan mendasar tersebut, penulis berusaha mengkaji secara jernih, serta berupaya mencari solusi terbaik bagi Aceh dan Negara Kesatuan Republik Indonesia. Sebagai langkah untuk mempermudah pembahasan, maka penulis menggunakan beberapa metode diantaranya:

(1) historical method, ${ }^{2}$ yaitu dengan mengumpulkan beberapa dokumen, dan juga data sejarah yang valid berkenaan dengan Aceh, kemudian mengolah

\footnotetext{
${ }^{1}$ Sofyan Tan, "Pendidikan Multikulturalisme: Solusi Ancaman Disintegrasi Bangsa," Jurnal Antropologi Sosial Budaya ETNOVISI, Vol. II No. 1, April 2006, h.32.

${ }^{2}$ Koentjara Ningrat, Metode-Metode Penelitian Masyarakat, Gramedia Pustaka Utama, h.160
} 
data tersebut untuk kemudian menganalisa lebih lanjut. Hal ini dilakukan untuk mengetahui tentang sejarah Aceh, hingga munculnya pemberontakan dari sebagian masyarakat Aceh.

(2) Analytic critic method, ${ }^{3}$ cara ini digunakan dengan menggambarkan fakta-fakta yang penulis dapatkan dari sumber-sumber tertentu untuk kemudian dianalisa dengan sumber-sumber yang lain. Dengan metode kritis analitis penulis dapat mencerna data-data yang ada untuk mencapai tujuan yang dikehendaki.

\section{Aceh dan Ancaman Konflik Disintegrasi Bangsa}

Jauh sebelum kemerdekaan RI di pertengahan abad ke-12, Islam diperkirakan telah masuk ke wilayah Sumatera dan terlibat kontak dagang antara utusan Arab dari Kekhalifahan Abbasiyah dengan kerajaan Sriwijaya. ${ }^{4}$ Dalam sumber lain dikatakan, bahwa Samudra Pasai (Sekarang Aceh Utara, Lhokseumawe) merupakan kerajaan Islam pertama di Nusantara dengan Sultan Malik al-Saleh sebagai raja muslim pertama di kerajaan tersebut. Baru kemudian di abad ke-16 Kesultanan Aceh mampu mencapai puncak kejayaannya di bawah kepemimpinan Sultan Ali Mughayat Syah, sebagai Sultan pertama yang meletakkan dasar-dasar berdirinya Kesultanan Aceh. Selama periode tersebut Kesultanan Aceh menguasai perdagangan di wilayah Aceh Besar, Daya, Pidie, dan Pasai sebagai penghasil rempah-rempah dan kapur barus. ${ }^{5}$

Berdasarkan historis, Aceh senantiasa mengalami pergolakan sepanjang masa disebabkan karena etnis Aceh selalu diingkari oleh pihak-pihak yang pernah memperoleh jasa dan budi baik rakyat Aceh. Termasuk dalam hal ini Belanda yang pernah berjuang selama 80 tahun merebut kemerdekaan dari penjajah Spanyol di tahun 1568-1648 M, dan berhasil menjadi negara merdeka tidak luput dari jasa kesultanan Aceh saat itu. Sultan Aceh-lah yang memberi pengakuan pertama atas kemerdekaan Belanda, baru kemudian menyusul negara-negara lain di dunia. Sultan Aceh dengan gelar Sultan Alaidin Riayatsyah ketika itu mengirim pernyataan pengakuan itu dengan sepucuk surat resmi kepada Raja Belanda pada tahun 1602 M. Namun, karena tergiur dengan sumber daya alam yang berlimpah, dengan watak Barat yang berambisi menjajah bangsa Timur, Belanda melanjutkan niatnya untuk menjajah Nusantara termasuk Aceh. Belanda mempersiapkan perang semesta untuk menaklukkan Aceh. Hingga akhirnya Belanda mendapat kemenangan atas Aceh, namun hal tersebut bukan membuat situasi aman, tenteram dan damai usai perang, justru perang melawan

\footnotetext{
${ }^{3}$ Suriasmantri Jujun, Penelitian Ilmiah, Kefilsafatan, dan Keagamaan, Pusjarlit Nuansa, h.45.

${ }^{4}$ Djenar Respati, Sejarah Agama-Agama Di Indonesia: Mengungkap Proses Masuk dan Perkembangannya, Cetakan I, (Yogyakarta: Araska, Oktober 2014), h.107-108.

${ }^{5}$ Saifullah, Sejarah \& Kebudayaan Islam Di Asia Tenggara, Cetakan I, (Yogyakarta: Pustaka Pelajar, 2010), h. 26-28.
} 
Belanda bagi rakyat Aceh makin berkecamuk selama 30 tahun (1873-1908), ${ }^{6}$ terlebih setelah Sultan Alaiddin Muhammad Dausyah (Sultan Aceh terakhir) turun di medan perang, bergerilya bersama rakyat melawan serdadu Belanda di hutan-hutan Aceh Timur, Aceh Utara dan Pidie. Itu sebabnya gejolak yang paling menonjol di Aceh adalah di ketiga kabupaten ini. Momentum tersebut dimanfaatkan dengan baik oleh rakyat Aceh, sehingga Belanda tidak pernah menjamah daerah Aceh sampai menjelang era Proklamasi Kemerdekaan Republik Indonesia tanggal 17 Agustus 1945.

Aceh juga menjadi basis kekuatan yang menggerakkan perang semesta, tanpa Aceh saat itu bisa jadi NKRI tidak dapat mewujudkan kemerdekaan penuh atas okupasi Belanda. Pasca kemerdekaan, tepatnya di bulan Juni 1948, Kesultanan Aceh menjadi tempat pelarian Ir. Soekarno ${ }^{7}$ ketika Yogyakarta (Ibu kota Indonesia saat itu) direbut kembali oleh Belanda pada peristiwa agresi militer Belanda ke-2. Artinya Aceh-lah sebagai wilayah utama NKRI saat itu, sedangkan wilayah lain di Indonesia menjadi negara bagian yang beribukota di Den Haag, Belanda. Dalam kunjungan tersebut, Bung Karno meminta rakyat Aceh untuk berdharma bhakti kepada perjuangan menegakkan RI, sehingga terhimpun dana sumbangan rakyat Aceh berupa emas murni dan harta benda lainnya. Karena hal tersebut Aceh disebut sebagai negara modal. Modal tersebut kemudian digunakan untuk membeli 2 pesawat terbang, yang diberi nama Seulawah RI 001 dan RI 002. Dalam perjuangan menegakkan dan mempertahankan kemerdekaan RI, lahirlah pemerintah darurat RI (PDRI) ${ }^{8}$ di bawah pimpinan Mr. Syafruddin Prawiranegara, dan menetapkan Aceh sebagai ibu kota dan pusat komando Panglima Sumatera di bawah Komando R. Hidayat. Kutaradja (Banda Aceh) digunakan sebagai pusat pembinaan Angkatan Laut dan Angkatan Udara RI. Namun, sekembalinya Bung Karno dari Aceh, justru keluarlah surat keputusan Presiden bahwa Aceh hanya sebagai bagian daerah Sumatera Utara dan menjadi bagian kecil Sumatera Utara.

Dari sini mulai muncul konflik disintegrasi bangsa di Aceh. Ketidakpuasan rakyat Aceh atas keputusan tersebut memunculkan gerakan DI/TII Pimpinan Kartosuwiryo di Jawa Barat yang dimanfaatkan rakyat Aceh untuk mengambil kesempatan menentang RI, dengan memproklamirkan negara Islam Aceh Darussalam. Sebagai reaksi atas gerakan rakyat Aceh tersebut, Perdana Menteri Muhammad Natsir bersikap pro-aktif melalui pendekatan persuasif dan empatif, ${ }^{9}$ sehingga situasi damai dan tenteram dapat terwujud. Aceh mendapatkan gelar "Daerah Istimewa Aceh."

\footnotetext{
${ }^{6}$ Microsoft Encarta 2003.

${ }^{7}$ Abbas Abdullah, Mengapa Aceh Bergolak sepanjang Masa, Harian kompas, Minggu, 15 April 2001.

${ }^{8}$ Abbas Abdullah, Ibid.

${ }_{9}^{9}$ Abbas Abdullah, ibid.
} 
Masa Orde Baru, kembali rakyat Aceh teringkari dengan lahirnya inspirasi baru yang bertentangan dengan NKRI, yaitu Gerakan Aceh Merdeka (GAM) yang lahir pada 4 Desember 1976. ${ }^{10}$ Ide GAM sangat bertentangan dengan hukum dan perundang-undangan di Indonesia, namun GAM terus bergolak tanpa kenal damai. Terhitung sejak Orde Baru hingga era reformasi, pemerintah tetap bertindak berdasarkan hukum yang tidak pernah tuntas. Untuk mengamankan Aceh di zaman Orde Baru ditetapkan Aceh sebagai Daerah Operasi Militer (DOM), namun justru hanya membuat banyak rakyat Aceh menjadi korban. Konflik disintegrasi antara rakyat Aceh dan pemerintah pun semakin runcing.

Di era Reformasi, Aceh semakin bergejolak karena di saat yang sama, Indonesia juga sedang menghadapi krisis di berbagai bidang lainnya. Janji Presiden Habibie untuk menuntaskan masalah Aceh juga tidak jadi kenyataan. Lepasnya Timor Timur makin mendorong semangat GAM untuk melepaskan diri dari NKRI. Namun anggota Dewan Perwakilan Rakyat menolak referendum rakyat Aceh, karena bertentangan dengan hukum dan perundang-undangan. Ancaman disintegrasi bangsa pun tidak dapat dihindari, sehingga diperlukan adanya resolusi konflik yang tepat untuk menanganinya.

\section{Perjanjian Helsinki dan Resolusi Konflik di Aceh}

Penyelesaian Aceh dengan menggunakan kekerasan seperti yang dilakukan Orde Baru tidak membawa hasil yang signifikan, bahkan menimbulkan reaksi luar negeri dengan membawa kedok hak asasi manusia. Pemerintah RI yang berniat baik menyelesaikan masalah justru dituduh melanggar HAM. Selain itu, penyelesaian konflik di Aceh dengan cara kekerasan hanya menambah jumlah penduduk sipil yang menjadi korban operasi.

Resolusi konflik merupakan suatu cara dalam menyelesaikan suatu permasalahan, dengan menggunakan cara yang demokratis dan konstruktif baik antara pihak yang berkonflik atau melalui pihak ketiga yang netral dan adil dalam memecahkan konflik yang terjadi ${ }^{11}$. Dalam hal ini resolusi konflik merupakan salah satu upaya pemerintah dalam memecahkan konflik di Aceh yang berpotensi menjadi konflik disintegrasi bangsa.

Meminjam istilah Albert Einstein "Peace cannot be kept by force. It can only be achieved by understanding, ${ }^{12}$ perdamaian tidak akan pernah tercapai dengan kekerasan tetapi dia hanya dapat dicapai dengan saling memahami. Perdamaian tidak akan didapatkan dengan cara membiarkan konflik yang terjadi berjalan

\footnotetext{
${ }^{10}$ Kamaruzzaman Bustaman Ahmad, Wajah Baru Islam di Indonesia, h.199.

${ }^{11}$ Wisnu Suhardono, "Konflik dan Resolusi" dalam Jurnal Salam: Jurnal Sosial dan Budaya Syar'i, Vol. II No. 1, Juni 2015, h.5.

12 Ruth Fishel, Five minutes for World Peace Forever, h.29.
} 
tanpa adanya penyelesaian. Kata orang bijak "Belajarlah dari sejarah" maka kita perlu membaca dan mengkaji ulang histori Aceh dengan seksama untuk memahami problem solving yang tepat dan bijak atas kasus Aceh. Perang adalah hal yang sangat mengerikan, dalam perang diperlihatkan bagaimana seorang ayah mengubur anak, istri dan bahkan teman sekalipun, begitu juga berapa banyak harta benda dikorbankan dalam sebuah peristiwa perang.

Diantara langkah-langkah yang diambil pemerintah dalam menyelesaikan masalah Aceh adalah dengan membuka peluang dialog guna menyelesaikan masalah yang dihadapi. Melalui dialog yang baik, dapat dipahami lebih lanjut tentang apa yang diinginkan rakyat Aceh untuk pembangunan wilayah mereka dan pemerintah juga dapat mengetahui sebabsebab timbulnya pemberontakan rakyat Aceh yang ingin memisahkan diri dari pemerintahan Indonesia. Selain itu pemerintah juga dapat menciptakan fleksibilitas dalam diplomasi guna tercapainya kesepakatan bersama yang tidak berat sebelah. Hal yang dapat dilakukan diantaranya dengan memperbaiki taraf hidup rakyat Aceh untuk memupuk kepercayaan rakyat demi perdamaian dapat diwujudkan.

Sebagai upaya membuka ruang dialog dengan rakyat Aceh, maka pemerintah membutuhkan langkah-langkah strategis, yaitu menghadirkan pihak ketiga dari International Non-Governmental Organization (INGO) antara lain Henry Dunant Centre (HDC) pada tahun 1999 dan berakhir di tahun 2003. Kemudian menghadirkan Crisis Management Initiative (CMI) pada tahun 2005. Tarik ulur antara kedua belah pihak berlangsung selama 8 bulan dalam 5 kali putaran hingga akhirnya menghasilkan nota kesepahaman (MoU) Helsinki. ${ }^{13}$

Melalui Perjanjian Helsinki yang menghasilkan lima kesepakatan utama, yait; ${ }^{14}$ Pertama, tentang penyelenggaraan pemerintahan di Aceh, yang mencakup undang-undang tentang penyelenggaraan pemerintahan di Aceh, partisipasi politik, perekonomian, dan peraturan perundang-undangan; Kedua, tentang Hak Asasi Manusia; Ketiga, tentang amnesti dan reintegrasi ke dalam masyarakat; Keempat, tentang pengaturan keamanan, yang dalam hal ini fokus terhadap hak dan kewajiban antara pemerintah RI dengan GAM; dan Kelima, tentang pembentukan misi monitoring Aceh yang dibentuk oleh Uni Eropa dan negaranegara ASEAN yang mendapat mandat memantau pelaksaan komitmen para pihak dalam nota kesepahaman tersebut.

Berdasarkan isi perjanjian tersebut, maka disusunlah Undang-Undang Pemerintahan Aceh (UUPA) sebagai wujud realisasi dari nota kesepahaman

\footnotetext{
${ }^{13}$ Muhammad Iqbal, "Fenomena Kekerasan Politik Di Aceh Pasca Perjanjian Helsinki" dalam Jurnal Hubungan Internasional, Tahun VII, No. 2, Juli-Desember 2014, h.154.

${ }^{14}$ Amal Ihsan Hadian, "Apa Isi Naskah Perjanjian Helsinki RI-GAM?" dalam News Data Financial Tool Kontan.co.id, Sabtu 6 April 2013, 22.30 WIB, diakses dari http://nasional.kontan.co.id/news/apa-isi-naskah-perjanjian-helsinki-ri-gam
} 
(MoU) antara pemerintah RI dan pihak GAM di Helsinki Finlandia tanggal 15 Agustus 2006 tersebut. ${ }^{15}$ Meskipun banyak yang berpendapat bahwa UndangUndang tersebut tidak menghasilkan perdamaian positif di Aceh karena sebagian isi dari UUPA tidak sesuai dengan isi kesepakatan. Pada dasarnya pemberian otonomi khusus merupakan pelimpahan wewenang kepada pemerintah Aceh dalam hal pembangunan dan politik daerah sebagaimana diatur dalam UU No. 11 Tahun 2006. Adapun nilai-nilai mengenai keistimewaan Aceh berlandaskan pada UU No. 44 Tahun 1999. ${ }^{16}$ Proses pembuatan UU inipun melibatkan banyak pihak dan menggunakan metode pendekatan bottom up (unsur-unsur pemerintahan kepada masyarakat Aceh) sekaligus top down (masyarakat Aceh memberikan masukan kepada pemerintah). ${ }^{17}$

Dengan dicetuskannya perjanjian Helsinki, rakyat Aceh memulai babak baru perdamaian Aceh, sehingga diharapkan konflik di Aceh selesai dan masyarakat berada dalam kedamaian, sehingga mampu berkonsentrasi membangun daerahnya. GAM sendiri mulai aktif dalam partisipasi politik salah satunya melalui partai politik di Aceh, meskipun terdapat permasalahan kepemimpinan dalam tubuh GAM tentang siapa tokoh yang mampu mempengaruhi GAM pada langkah berikutnya. ${ }^{18}$ Bercermin dari perjalanan Rasulullah saw, ketika orang-orang kafir Mekkah mengadakan perjanjian dengan kaum Muslimin yang terkenal dengan perjanjian Hudaibiyya, ${ }^{19}$ dalam perjanjian tersebut, walaupun banyak sahabat yang menganggap bahwa perjanjian itu banyak merugikan kaum Muslimin, namun Rasulullah saw tetap berkomitmen untuk menerima isi perjanjian tersebut. Meskipun akhirnya orangorang kafir melanggar perjanjian damai tersebut. Rasulullah saw menindak tegas bagi mereka yang melanggar perjanjian, sebagaimana Pemerintahan RI yang bersikukuh dalam menjaga perjanjian dan menindak tegas bagi mereka yang melanggarnya.

Langkah berikutnya sangat ditentukan oleh pihak-pihak terkait, terutama pihak GAM dan Pemerintah Indonesia supaya mentaati butir-butir draf kesepakatan damai dengan tindakan nyata yang mendukung terciptanya perdamaian.

${ }^{15}$ Suadi Zainal, "Transformasi Konflik Aceh dan Relasi Sosial-Politik di Era Desentralisasi" dalam Jurnal MASYARAKAT: Jurnal Sosiologi, Vol. 21, No. 1, Januari 2016, h.82.

${ }^{16}$ Zaki ‘Ulya, "Refleksi Memorandum of Understanding (MoU) Helsinki dalam Kaitan Makna Otonomi Khusus di Aceh" dalam Jurnal Konstitusi, Volume 11, Nomor 2, Juni 2014, h.390-391.

${ }^{17}$ Aleksius Jemadu, "Proses Peacebuilding di Aceh: Dari MoU Helsinki Menuju Implementasi Undang-Undang tentang Pemerintahan Aceh" dalam Jurnal Hukum Internasional, Volume 3 Nomor 4 Juli 2006, h.542.

${ }_{18}$ Anton Aliabbas, Transformasi Gerakan Aceh Merdeka, Beranda Perdamaian Aceh Tiga Tahun Pasca MoU Helsinki, P2P LIPI dan Pustaka Pelajar, January 2008, h.28-31.

${ }^{19}$ Lihat, Muhammad Munir, Public International Law and Islamic International Law, Identical Expressions of World order, Islamabad Law Law Revie, h.391. 
Seluruh rakyat tentunya memiliki harapan, supaya pihak-pihak yang selama ini berseteru akan memegang teguh kesepakatan damai yang telah dihasilkan di Helsinki. Harapan itu sangat besar, karena pada hakikatnya apa yang dilakukan oleh para pihak yang 'bertikai' -baik GAM maupun Pemerintah RI- adalah untuk kepentingan rakyat Aceh. Untuk kemajuan dan kesejahteraan rakyat di tanah rencong dan demi mempertahankan keutuhan NKRI.

Pasca perjanjian Helsinki terdapat empat agenda pembangunan hukum yang bersifat mendesak sebagai implikasi MoU Helsinki, yaitu; (1) pembentukan Undang-Undang tentang Penyelenggaraan Pemerintahan di Aceh (PPA), (2) Merumuskan dan menyusun ulang Qanun (Peraturan Daerah), (3) Pengembangan sistem dan mekanisme penyelesaian klaim tanah pertanian, kesempatan pekerjaan dan jaminan sosial, serta pembentukan Komisi untuk itu, (4) Pembenahan aparatur penegak hukum, yaitu kepolisian, kejaksaan, pengadilan, termasuk Mahkamah Syariah.

\section{Penerapan Perda Syariah di Aceh}

Islam menjadi pertimbangan penting dalam berbagai kebijakan negara pada berbagai tingkatnya, seperti tercermin dalam berbagai keputusan dan langkah yang diambil para pejabat negara, baik dalam lembaga eksekutif, legislatif, maupun yudikatif. Penerapan syariat Islam di bumi Nangroe Aceh Darussalam merupakan hak bagi rakyat Aceh didasarkan pada sejarah Aceh sebagai wilayah masuknya Islam pertama kali di Indonesia. Aceh juga sebagai wilayah yang berdaulat pada masa kesultanan Islam dan dari Aceh perlawanan melawan kolonial Belanda digerakkan. ${ }^{20}$ Dengan demikian, hak istimewa bagi Aceh merupakan hak yang memang harus diberikan kepada rakyat Aceh.

Sebagai bangsa yang besar hendaknya mampu memberikan hak-hak setiap warga negaranya. Sebaliknya, hal yang harus dilakukan masyarakat Aceh yaitu melakukan kewajiban mereka sebagai warga negara Indonesia dengan baik, yaitu dengan taat dan patuh dibawah naungan Negara Kesatuan Republik Indonesia.

Penerapan syariat Islam bukan hanya diartikan sebagai penerapan sebagian undang-undang, namun penerapan undang-undang secara keseluruhan, baik di bidang sosial, ekonomi, politik dan hukum. Penerapan syariat Islam merupakan hak yang harus dipenuhi, dan patuh terhadap negara kesatuan RI adalah kewajiban yang harus dipenuhi. Karena tidak ada hak-hak tanpa adanya kewajiban dan tidak ada kewajiban tanpa adanya hak-hak. ${ }^{21}$ Hak-hak masyarakat Aceh adalah mendapatkan hasil bumi mereka dan dapat

${ }^{20}$ Lihat, Majalah al-Mujtama' edisi 1667, 3 september 2005, h.15.

${ }^{21}$ Hasan Hanafi, "At-tasyri' al-Jinai al-Islami baina al-huquq wa al-wajibat," Harian al-Ittihad, sabtu 4 juni 2005. 
menerapkan syariat Islam. Apabila hak-hak tersebut sudah dipenuhi, maka mereka dituntut untuk tetap patuh di bawah naungan NKRI.

Penerapan Perda Syariah di Aceh menuai pro kontra di masyarakat. Ketua Partai Solidaritas Indonesia (PSI) Grace Natalie, dengan lantang menyuarakan bahwa PSI menolak perda-perda yang berlandaskan agama, baik perda syariah di Aceh maupun perda Injil di Papua dengan alasan untuk membela kebhinekaan. ${ }^{22}$ Pernyataan tersebut sontak memancing kontroversi di masyarakat, terutama di kalangan pendukung perda-perda berbasis agama khususnya perda syariah. Penolakan terhadap perda agama ini pun didukung oleh Partai Demokrasi Indonesia-Perjuangan, perda syariah menurut PDIP tidak ada, karena semua perundang-undangan harus turunan dari konstitusi.

Mantan ketua Mahkamah Konstitusi, Mahfudz MD menyatakan bahwa hukum syariah merupakan hukum perdata yang tidak perlu dirumuskan dalam bentuk perda dan hanya akan sia-sia. ${ }^{23}$ Pernyataan tersebut sebagaimana dilansir dalam tempo pada tanggal 18 November 2018, sebagai reaksi atas kontroversi penolakan perda syariah oleh ketua umum Partai Solidaritas Indonesia. Dalam hal ini, mahfudz MD lebih memandang syariah Islam sebagai sebuah sistem nilai yang sudah seharusnya diinternalisasikan dalam diri individu rakyat Indonesia dan bukan sebagai produk nilai yang harus dimasukkan dalam sebuah aturan khusus.

Sementara Sandiaga Salahuddin Uno mendukung penerapan perda syariah yang menurutnya sebagai bagian dari kearifan lokal suatu daerah yang tidak perlu digugat dan diperdebatkan lagi eksistensinya. Bagi Sandi, perda syariah dinilai mampu mendorong penerapan Islam secara kaffah dan mampu menjadi problem solving dalam hal ekonomi dan moral masyarakat. ${ }^{24}$ Hal tersebut dikemukakan saat silaturahmi bersama ulama Aceh di hotel Hermes, Banda Aceh.

Nilai-nilai Islam sendiri sebenarnya telah menjadi suatu sistem nilai dalam Pancasila dan Pembukaan UUD 1945. Teks Pancasila sendiri sebelum menjadi format baku seperti saat ini, sila pertama berbunyi "Ketuhanan dengan kewajiban menjalankan syariat Islam bagi pemeluk-pemeluknya," sebagaimana dirumuskan dalam Piagam Jakarta, 22 Juni 1945 sebagai hasil kesepakatan

${ }^{22}$ Radix Wp, "PSI Kontra Perda Syariah" dalam Kolom detiknews, Senin 26 November 2018, diakses dari https://m.detik.com/news/kolom/4317388/psi-kontra-perda-syariah

${ }^{23}$ Francisca Christy Rosana, Mahfudz MD: Perda Syariah dan Perda Sejenisnya Hanya Sia-sia, tempo.co, minggu 18 November 2018, 07.13 WIB, diakses dari https://nasional.tempo.co/read/1147392/mahfud-md-perda-syariah-dan-perda-sejenisnya-hanya$\underline{\text { sia-sia }}$

${ }^{24}$ CNN Indonesia, "Sandi Sebut Perda Syariah Perlu Didukung dan Jangan Diganggu," Rabu 21 November 2018, 07.42, Diakses dari https://m.cnnindonesia.com/nasional/20181121065828-32347978/sandi-sebut-perda-syariah-perlu-didukung-jangan-diganggu 
pertama sidang. ${ }^{25} \mathrm{Hal}$ tersebut tidak terlepas dari histori panjang bangsa Indonesia dalam memperjuangkan kemerdekaan, dimana tidak terlepas dari peran para ulama dan umat Islam di nusantara termasuk kesultanan Aceh.

Berdasarkan sisi historis, rakyat Aceh telah melalui 5 periode dalam upaya mewujudkan legalitas hukum dari pemerintahan pusat dalam menerapkan syariat Islam di Aceh, yaitu; pertama, masa Kesultanan Aceh; kedua, masa penjajahan Belanda; ketiga, masa awal kemerdekaan; keempat, masa orde baru; dan kelima, masa reformasi ${ }^{26}$. Hal tersebut sebagai upaya dalam mempertahankan jati diri masyarakat Aceh sebagai wilayah Kesultanan Aceh di masa silam.

Islam bukan agama yang penuh kekerasan dan permusuhan. Islam adalah agama rahmatan lil'alamin. Islam merupakan kepercayaan, ketundukan, dan juga jalan yang membatasi hak-hak dari kewajiban-kewajiban. Islam membawa kebaikan bagi seluruh manusia, mengatur setiap segi kehidupan berdasarkan al-Qur'an dan al-Hadist, baik dalam segi kehidupan sosial masyarakat, mempertahankan kehormatan dan menjaga dari setiap kerusakan dan kejahatan. ${ }^{27}$ Sehingga penerapannya di bumi Aceh tidak perlu dikhawatirkan.

Syariat Islam tidak akan mendatangkan problem bagi masyarakat Aceh maupun masyarakat di luar Aceh. Masyarakat Aceh adalah masyarakat Islam. Jauh sebelum kemerdekaan, di Aceh telah berdiri kerajaan Islam yang mengimplementasikan tata hukum Islam. Hukum Islam di Aceh berlaku sejak abad ke-14 sampai abad ke-19. Hukum Islam adalah bagian dari adat-istiadat masyarakat Aceh. Baru pada tahun 1907 sampai sekarang, hukum Islam tidak berlaku di Aceh. Adapun jika ada wilayah lain yang menuntut hal yang sama seperti Aceh, itu bukan karena penerapan syariat Islam di Aceh, melainkan karena kurangnya rasa keadilan yang mereka rasakan dari Pemerintahan pusat sehingga mereka menuntut hak-haknya melalui berbagai macam cara untuk mencapainya.

\section{Kesimpulan}

Aceh sudah lama merasakan penderitaan, sejak zaman sebelum kemerdekaan hingga pasca kemerdekaan dan reformasi saat ini. Rakyat Aceh tidak mendapatkan hak-hak mereka sebagaimana mestinya, sehingga wajarlah timbul perlawanan yang tak kunjung reda hingga kini. Hendaknya penandatanganan nota kesepahaman di Helsinki dapat memberikan hal terbaik

\footnotetext{
${ }^{25}$ Kaelan, Pendidikan Pancasila, Edisi Revisi Kesebelas, (Yogyakarta: Paradigma, 2016), h.15 ${ }^{26}$ Syamsul Bahri, "Pelaksanaan Syariat Islam Di Aceh Sebagai Bagian Wilayah Negara Kesatuan Republik Indonesia (NKRI)" dalam Jurnal Dinamika Hukum, Vol. 12 No. 2, Mei 2012, h.360-361.

27 Sholah As-Showi, Qodiyyatu Tatbiiqu al-Syariat fi al-Alam al-Islami, h.138.
} 
bagi masyarakat Aceh. Memberikan hak-hak rakyat Aceh dengan semestinya, baik dalam mengatur sumber daya alam ataupun dalam penerapan syariat Islam berdasarkan al-Qur'an dan al-Hadist. Dengan menerima hak-hak rakyat Aceh dengan semestinya, diharapkan rakyat Aceh melaksanakan kewajiban mereka sebagai warga negara Indonesia dan tetap tunduk terhadap NKRI, sebagaimana yang tertera dalam nota kesepahaman di Helsinki.

Konflik Aceh diharapkan dapat dijadikan sebagai langkah awal percontohan bagi penyelesaian berbagai macam masalah di tanah air, yaitu melalui metode persuasif, pendekatan, dan dialog dalam upaya menegakkan keadilan dengan memberikan hak-hak kepada masyarakat Aceh sesuai perundang-undangan. Pemenuhan hak diharapkan tidak ada lagi wilayah lain yang merasa iri. Optimistis terhadap hasil perjanjian Helsinki merupakan awal yang baik untuk terciptanya perdamaian di bumi Rencong dan menjadi percontohan bagi wilayah lainnya di Indonesia, yaitu penyelesaian setiap masalah melalui diplomasi perundingan bukan dengan kekerasan. Diharapkan juga agar semua pihak menjaga komitmen untuk menjaga isi perjanjian yang disepakati dalam draf (MoU), baik dari pihak RI, GAM dan pemantau luar negri atau Aceh Monitoring Mission (AMM).

\section{Daftar Pustaka}

'Ulya, Zaki. "Refleksi Memorandum of Understanding (MoU) Helsinki dalam Kaitan Makna Otonomi Khusus di Aceh" dalam Jurnal Konstitusi, Volume 11, Nomor 2, Juni 2014.

Abdullah, Abbas. Mengapa Aceh Bergolak Sepanjang Masa, Harian kompas, Minggu, 15 April 2001.

Ahmad, Kamaruzzaman Bustaman. Wajah Baru Islam di Indonesia, Yogyakarta: UII Press Yogyakarta, Juni 2004.

Aji, Ahmad Mukri. "Pemberatasan Tindak Pidana Terorisme di Indonesia (Analisis Terhadap Undang-Undang Nomor 15 dan 16 Tahun 2003 Berdasarkan Teori Hukum)," dalam Jurnal Cita Hukum, Vol. 1, No. 1 (2013).

Aji, Ahmad Mukri. Kontekstualisasi Ijtihad Dalam Diskursus Pemikiran Hukum Islam di Indonesia, Bogor: Pustaka Pena Ilahi, 2010.

Aji, Ahmad Mukri. Urgensi Maslahat Mursalah Dalam Dialektika Pemikiran Hukum Islam, Bogor: Pustaka Pena Ilahi, 2012.

Aliabbas, Anton. Transformasi Gerakan Aceh Merdeka, Beranda Perdamaian Aceh Tiga Tahun Pasca MoU Helsinki, P2P LIPI dan Pustaka Pelajar, January 2008.

Al-Shawi, Sholah. Qodiyyatu Tatbiq As-syariah fi-al-Alam al-Islami, tahun 1990. 
Bahri, Syamsul. "Pelaksanaan Syariat Islam Di Aceh Sebagai Bagian Wilayah Negara Kesatuan Republik Indonesia (NKRI)" dalam Jurnal Dinamika Hukum, Vol. 12 No. 2, Mei 2012.

Fishel, Ruth. Five Minutes for world Peace Forever. Health Communicatioans, Inc. Florida.

Hanafi, Hasan. At-Tasyri' al-Jinai al-Islami Baina al-Huquq wa al-Wajibat, Harian Al-Ittihad, sabtu 4 Juni 2005.

Iqbal, Muhammad. "Fenomena Kekerasan Politik Di Aceh Pasca Perjanjian Helsinki" dalam Jurnal Hubungan Internasional, Tahun VII, No. 2, Juli-Desember 2014.

Jemadu, Aleksius. "Proses Peacebuilding di Aceh: Dari MoU Helsinki Menuju Implementasi Undang-Undang tentang Pemerintahan Aceh" dalam Jurnal Hukum Internasional, Volume 3 Nomor 4 Juli 2006.

Jujun, Suriasmantri. Penelitian Ilmiah, Kefilsafatan, dan Keagamaan, Bandung, Pusjarlit Nuansa, 1998.

Kaelan. Pendidikan Pancasila, Edisi Revisi Kesebelas, (Yogyakarta: Paradigma, 2016), h.15

Maggalatung, A Salman. "Hubungan Antara Fakta Norma, Moral, Dan Doktrin Hukum Dalam Pertimbangan Putusan Hakim," dalam Jurnal Cita Hukum, Vol. 2, No. 2 (2014).

Maggalatung, A Salman; Yunus, Nur Rohim. Pokok-Pokok Teori Ilmu Negara, Cet1, Bandung: Fajar Media, 2013.

Majalah al-Mujtama' Edisi 1667, 3 september 2005.

Microsoft Encarta 2003.

Munir, Muhammad. "Public International Law and Islamic International Law: Identical Expressions of world Order," dalam Jurnal Islamabad Law Review, Vol. 1, 2003.

Ningrat, Koentjara. Metode-Metode Penelitian Masyarakat, Jakarta Gramedia Pustaka Utama, 1991.

Respati, Djenar. Sejarah Agama-Agama Di Indonesia: Mengungkap Proses Masuk dan Perkembangannya, Cetakan I, (Yogyakarta: Araska, Oktober 2014).

Saifullah, Sejarah E Kebudayaan Islam Di Asia Tenggara, Cetakan I, (Yogyakarta: Pustaka Pelajar, 2010).

Suhardono, Wisnu. "Konflik dan Resolusi" dalam Jurnal Salam: Jurnal Sosial dan Budaya Syar-i, Vol. 2, No. 1, Juni 2015. 
Tan, Sofyan. "Pendidikan Multikulturalisme: Solusi Ancaman Disintegrasi Bangsa," Jurnal Antropologi Sosial Budaya ETNOVISI, Vol. II No. 1, April 2006.

Terjemahan Resmi (MoU) yang telah disetujui oleh delegasi RI dan GAM di Helsinki, Finlandia, 15 agustus 2005.

Zainal, Suadi. "Transformasi Konflik Aceh dan Relasi Sosial-Politik di Era Desentralisasi" dalam Jurnal MASYARAKAT: Jurnal Sosiologi, Vol. 21, No. 1, Januari 2016.

Website:

CNN Indonesia, "Sandi Sebut Perda Syariah Perlu Didukung dan Jangan Diganggu," Rabu 21 November 2018, 07.42, Diakses dari

https://m.cnnindonesia.com/nasional/20181121065828-32-347978/sandisebut-perda-syariah-perlu-didukung-jangan-diganggu

Francisca Christy Rosana, Mahfudz MD: Perda Syariah dan Perda Sejenisnya Hanya Sia-sia, tempo.co, minggu 18 November 2018, 07.13 WIB, diakses dari https://nasional.tempo.co/read/1147392/mahfud-md-perda-syariah-danperda-sejenisnya-hanya-sia-sia

Hadian, Amal Ihsan. "Apa Isi Naskah Perjanjian Helsinki RI-GAM?" dalam News Data Financial Tool Kontan.co.id, Sabtu 6 April 2013, 22.30 WIB, diakses dari http://nasional.kontan.co.id/news/apa-isi-naskah-perjanjian-helsinkiri-gam

Radix Wp, "PSI Kontra Perda Syariah" dalam Kolom detiknews, Senin 26 November 2018, diakses dari https://m.detik.com/news/kolom/4317388/psi-kontra-perda-syariah 
Resolusi Konflik Pencegahan Disintegrasi Bangsa Melalui Legalitas Hukum Syariat di Aceh 